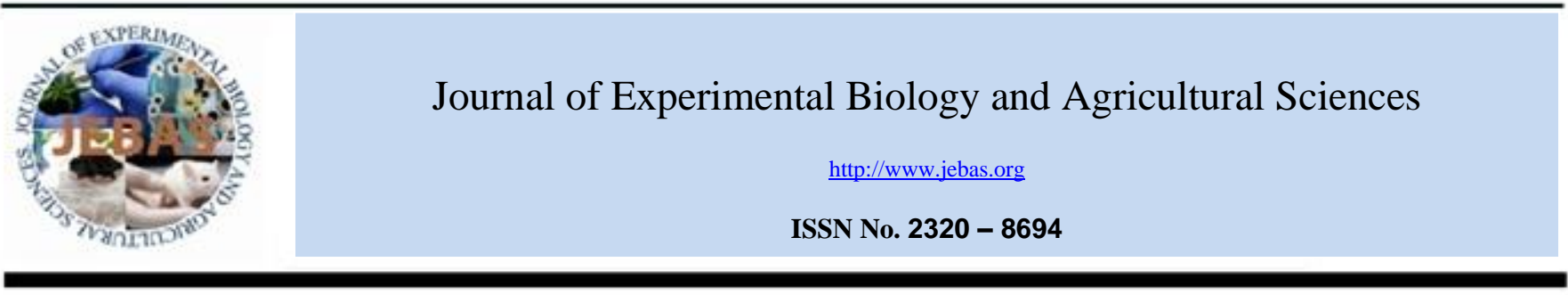

\title{
EFFECT OF TEMPERATURE AND LOADING DENSITY ON DRYING KINETICS OF WHEAT
}

\author{
Mojaffor Hosain ${ }^{1, *}$, Raihanul Haque ${ }^{2}$, Md. Nazrul Islam³ ${ }^{3}$ Habiba Khatun ${ }^{4}$ and Md. Shams-Ud-Din ${ }^{3}$ \\ ${ }^{1}$ Department of Food Processing and Preservation, Hajee Mohammad Danesh Science and Technology University, Dinajpur-5200 \\ ${ }^{2}$ Department of Food Engineering and Technology, Hajee Mohammad Danesh Science and Technology University, Dinajpur-5200 \\ ${ }^{3}$ Department of Food Technology and Rural Industries, Bangladesh Agricultural University, Mymensingh \\ ${ }^{4}$ Department of Food Science and Nutrition, Hajee Mohammad Danesh Science and Technology University, Dinajpur-5200
}

Received - February 19, 2016; Revision - March 17, 2016; Accepted - April 28, 2016

Available Online - April 28, 2016

DOI: http://dx.doi.org/10.18006/2016.4(2).210.217

\author{
KEYWORDS \\ Wheat \\ Drying kinetics \\ Cabinet dryer \\ Diffusion Coefficient \\ Activation energy
}

\begin{abstract}
The effect of temperature and loading density on drying kinetics of wheat were studied experimentally in a laboratory-scale cabinet dryer. The study was conducted at drying temperatures of 40,45 , and $50^{\circ} \mathrm{C}$ with loading density of 2.12 and $4.24 \mathrm{~kg} / \mathrm{m}^{2}$ at constant air velocity of $0.6 \mathrm{~m} / \mathrm{sec}$. The Henderson and Pabis model was applied to fit the drying conditions. Results of study revealed that drying rate constant gradually decreased with the increasing of loading density of wheat. The effective moisture diffusivity for wheat was increased with the increasing of drying temperature, and it was in the range of $3.27 \times 10^{-11}$ $\mathrm{cm}^{2} / \mathrm{sec}$ to $7.95 \times 10^{-11} \mathrm{~cm}^{2} / \mathrm{sec}$ while the activation energy of $17.64 \mathrm{kcal} / \mathrm{g}$-mole was found from the Arrhenius equation.
\end{abstract}

* Corresponding author

E-mail: engr.mojaffor@gmail.com (Mojaffor Hosain)

Peer review under responsibility of Journal of Experimental Biology and Agricultural Sciences.

Production and Hosting by Horizon Publisher India [HPI] (http://www.horizonpublisherindia.in/).

All rights reserved.
All the article published by Journal of Experimental Biology and Agricultural Sciences is licensed under a Creative Commons Attribution-NonCommercial 4.0 International License Based on a work at www.jebas.org.

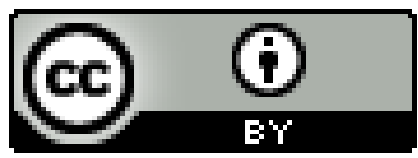




\section{Introduction}

Wheat (Triticum aestivum) belongs to the family Graminae, is one of the important cereals to make flour for diet and livestock feed. Wheat can be easily processed to flour and semolina. Further, wheat is also used as rich source of carbohydrate, fiber, vitamin B complex and minerals (Sramkova et al., 2009). It is believed that wheat is originated in the Nile Valley by 5000 BC and the Mediterranean region is the center of domestication (Zohary \& Hopf, 2000). In Bangladesh, wheat cultivation is started from the late 1980s. Firstly, it is consumed in rural areas but now, it is second highest consumed cereal crop (Banglapedia, 2006). According to BARI report 2010, about 1 million ton of wheat is produced against the annual demand of 3.0-3.5 million tons in Bangladesh. Consequently, 2.0-2.5 million tons of wheat is imported every year in Bangladesh to meet the national demand. On the other hand, postharvest loss of wheat is found almost $3.62 \%$ in Bangladesh, among this storage loss is $1.54 \%$. However, improved drying system with proper drying management is important to minimize the storage loss of wheat (Bala et al., 2010).

Drying is one of the oldest but important techniques to preserve and improving the storage quality of agricultural produces. Drying technique involves the removal of moisture content to safe level by means of heat and mass transfer (Ertekin \& Yaldiz, 2004), as a result of this, it prevents the enzymatic and microbial spoilage of food products. Furthermore, dried products need less space for storage and drying technique makes agricultural products easier to handle without losing remarkable amount of vitamins (Izadifar \& Mowla, 2003; Sagar \& Kumar, 2010). In Bangladesh, drying technique varies from natural sun drying to mechanical drying depending on product and affordability in cost. Sun drying is most common drying technique for wheat but it requires relatively long drying time and is associated with drying loss of wheat.

On the other hand, mechanical drying namely cabinet drying is alternative option with several advantages including high thermal conductivity, energy saving, better space utilization and precise controlling system (Maskan, 2000). Several researchers investigated drying characteristics of fruits and vegetables in various drying system. Thin layer drying characteristics of pomegranate arils with varying temperature $\left(50,55\right.$ and $\left.60^{\circ} \mathrm{C}\right)$ in cabinet drying system are studied by Kingsly \& Singh (2007). The effects of different drying temperatures and air velocity levels on drying behavior of carrot have been studied by Erenturk \& Erenturk (2007). In addition, different drying models are used to design dryers for efficient moisture transfer analysis along with to describe the drying behavior of agricultural produces (Midilli et al., 2002; Da Silva et al., 2009; Kumar et al., 2011).

Hence, present study was aimed to investigate the drying behavior of wheat with varying drying temperature and loading density (layer) in a cabinet dryer. Apart from this, effective diffusivities and activation energy were calculated in selected drying conditions.

\section{Materials and Methods}

\subsection{Sample collection}

The Prodip (BAW-1008) wheat was used in this study and collected from the central farm of Bangladesh Agricultural University during harvesting time. After collecting, wheat was winnowed to get fresh and quality sample material. On the same day, prepared sample was subjected to drying process.

\subsection{Drying process}

Drying process of wheat was accomplished in cabinet dryer (model OV-165, Gallenkamp Company), consists of several chambers in which samples were placed in trays. Usually, a fan is used for blowing air over a heater and above the samples placed in trays of cabinet dryer. The air velocity was measured by Anemometer.

Fresh wheat with known loading density $\left(2.12 \mathrm{~kg} / \mathrm{m}^{2}\right.$ and 4.24 $\mathrm{kg} / \mathrm{m}^{2}$ ) was subjected to cabinet drying process at three different dry bulb temperatures $\left(40,45\right.$ and $\left.50^{\circ} \mathrm{C}\right)$ with constant air velocity $(0.6 \mathrm{~m} / \mathrm{sec})$ to know the effect of loading density and temperature on drying kinetics of wheat.

\subsection{Theoretical consideration}

\subsubsection{Mechanical modeling of drying curves}

Different drying models are used to fit the drying curves to experimental data for determining most efficient drying model. An effective drying behavior model is very important to know the drying characteristics of wheat for a cabinet dryer. In this study, the experimental drying data of wheat at different conditions were fitted into Henderson and Pabis model given below (Figiel, 2010):

$\mathrm{MR}=\mathrm{a} \exp (-\mathrm{kt})$

The moisture ratio of fresh wheat was calculated by the following equation (Figiel, 2010):

$\mathrm{MR}=\left(\mathrm{M}_{\mathrm{t}}-\mathrm{M}_{\mathrm{e}}\right) /\left(\mathrm{M}_{\mathrm{o}}-\mathrm{M}_{\mathrm{e}}\right)$

Where, MR is moisture ratio, M0,Mt and Me are initial moisture content, moisture content at specific time and equilibrium moisture content ( $\mathrm{kg}$ water $/ \mathrm{kg} \mathrm{dm}$ ) respectively.

For low equilibrium moisture content and moisture ratio (MR< $0.6)$, equation reduces to

$\mathrm{MR}=\mathrm{M}_{\mathrm{t}} / \mathrm{M}_{\mathrm{o}} \quad \ldots(3)$ 
2.3.2 Effective moisture diffusivity

In drying process, moisture moves to surface by a physical mechanism known as diffusivity, which can be explained by Fick's diffusion equation (Abe \& Afzal, 1997). On the other hand, effective moisture diffusivity depends on chemical composition, temperature, density and porosity of substance (Perry et al., 1984). Several researchers have been stated that effective moisture diffusivity (Deff) of food substance can be calculated by 'methods of slope' technique (Karathanos et al., 1990; Zogzas et al., 1996; Sharma et al., 2005). It is assumed that food dehydration is occurred by diffusion process. Therefore,mass transfer during drying process can be described by Fick's second law of diffusion. The expression is:

$$
\frac{\delta M}{\delta T}=\nabla^{2} D_{e} M
$$

Where, $\mathrm{M}$ is moisture content (dry basis), $\mathrm{D}_{\mathrm{e}}$ is effective diffusion co-efficient and $\mathrm{T}$ is time (hr)

The above diffusion equation is usually used for a sphere shaped body such as grain with radius 'r' (Brooker et al., 1974; Crank, 1975; Islam, 1980) can be written as:

$M R=\frac{6}{\pi^{2}} \sum_{n=1}^{\infty} \exp \left\{\frac{-(2 n+1)^{2} \pi^{2} D_{e f f} t}{r^{2}}\right\}$

Where, $D_{\text {eff }}$ is the effective diffusivity $\left(\mathrm{m}^{2} / \mathrm{s}\right)$ and $\mathrm{r}$ is radius.

The equation (5) can be simplified by taking the first term of series (Tutuncu \& Labuza, 1996) and written as

$$
\begin{gathered}
M R=\frac{6}{\pi^{2}} \exp \left(-\frac{\pi^{2} D_{\text {eff }} t}{r^{2}}\right) \\
\text { or } \\
\ln M R=\ln \frac{6}{\pi^{2}}-\frac{\pi^{2} D_{\text {eff }} t}{r^{2}}
\end{gathered}
$$

The slope and effective diffusivity can be calculated from the above equation and written as:

$$
\begin{gathered}
\text { Slope }=\frac{\pi^{2} D_{\text {eff }}}{r^{2}} \\
\text { Again, } D_{\text {eff }}=\frac{r^{2}}{\pi^{2}}(\text { slope }) \\
\text { Where, slope }=\left(\operatorname{lnMR}_{2}-\operatorname{lnMR}_{1}\right) /\left(t_{2}-t_{1}\right)
\end{gathered}
$$

The temperature dependence of the effective diffusivity may be described by an Arrhenius-type relationship (Madamba et al., 1996; Ozdemir \& Devres, 1999; Sanjuan et al., 2003; Akgun \& Doymaz, 2005; Wang et al., 2006) and written as:

$$
\begin{gathered}
D_{\text {eff }}=D_{0} \exp \left(\frac{E_{a}}{R T}\right) \ldots \ldots \ldots \ldots . . .(9) \\
\text { or } \\
\ln D_{\text {eff }}=\ln D_{0}-\frac{E_{a}}{R T} \ldots \ldots \ldots . .(10)
\end{gathered}
$$

Where, $\mathrm{D}_{0}=$ frequency factor of Arrhenius equation $\left(\mathrm{m}^{2} / \mathrm{s}\right)$, Ea $=$ activation energy $(\mathrm{J} / \mathrm{mol}), \mathrm{T}=$ absolute temperature $(\mathrm{K})$ and $\mathrm{R}=$ universal gas constant $(\mathrm{J} / \mathrm{mol} \mathrm{K})$. The activation energy $\left(E_{a}\right)$ could be calculated from the slope of straight line of $1 n$ Deff versus reciprocal of $\mathrm{T}$.

3 Results and Discussion

\subsection{Effect of temperature on drying kinetics}

Wheat was dried at 40,45 and $50^{\circ} \mathrm{C}$ in thin layer to know the effects of temperature on drying kinetics of wheat, whereas experimental data were analyzed using equation (6). Moisture ratio was plotted against drying time on semi-log graph paper (Figure 1) and the regression equations were developed as below:

$$
\begin{aligned}
& \mathrm{MR}=0.9203 \mathrm{e}^{-0.226 \mathrm{t}} \text { at } 40^{\circ} \mathrm{C}----------------(11) \\
& \mathrm{MR}=0.9193 \mathrm{e}^{-0.285 t} \text { at } 45^{\circ} \mathrm{C} \text {-------------------- (12) } \\
& \mathrm{MR}=0.9062 \mathrm{e}^{-0.353 \mathrm{t}} \text { at } 50^{\circ} \mathrm{C}---------------------(13)
\end{aligned}
$$

From Figure (1) and above developed equations (11 to 13), it is clear that the moisture ratio (MR) decreased continuously with the drying progresses. Results of the study also revealed that drying time to a specific moisture ratio decreased with higher drying temperature of wheat. Figure (1) also suggests that drying rate constant gradually increased with the increasing of drying temperature. Higher temperature with low humidity may increase the drying rate at initial stage. But longer drying process would result in case hardening; therefore, it would reduce the drying rate significantly and deteriorate the product quality due to cooking instead of drying.

Similar findings have been stated by Sarker et al. (2012) for potato; Kumar et al. (2011) for carrot pomace; Khaliduzzaman et al. (2009) for garlic; Kamruzzaman \& Islam (2006) for aroids. Thus optimum drying temperature is crucial parameter in mechanical drying process with counter current operation (Karel et al., 1975; Potter \& Hotchkiss, 1978; Islam, 1980). 


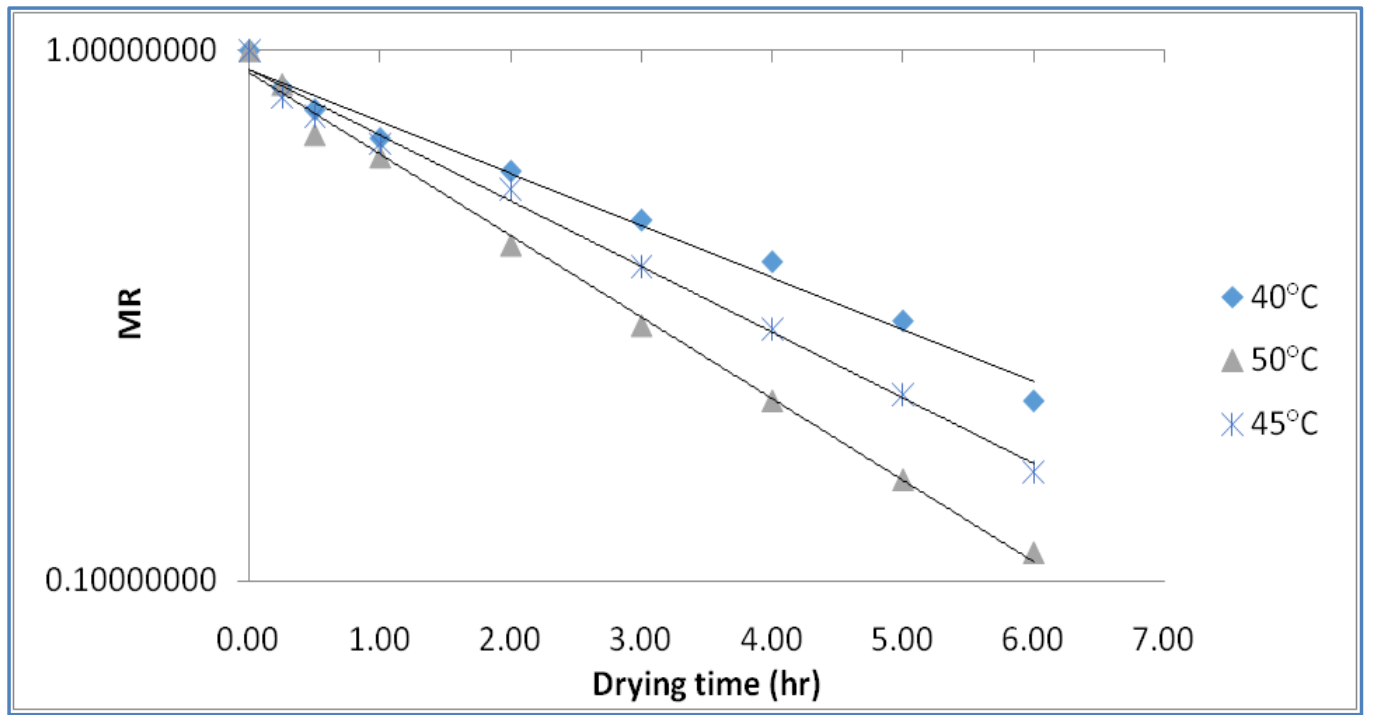

Figure 1 Effect of temperature on drying kinetics for wheat

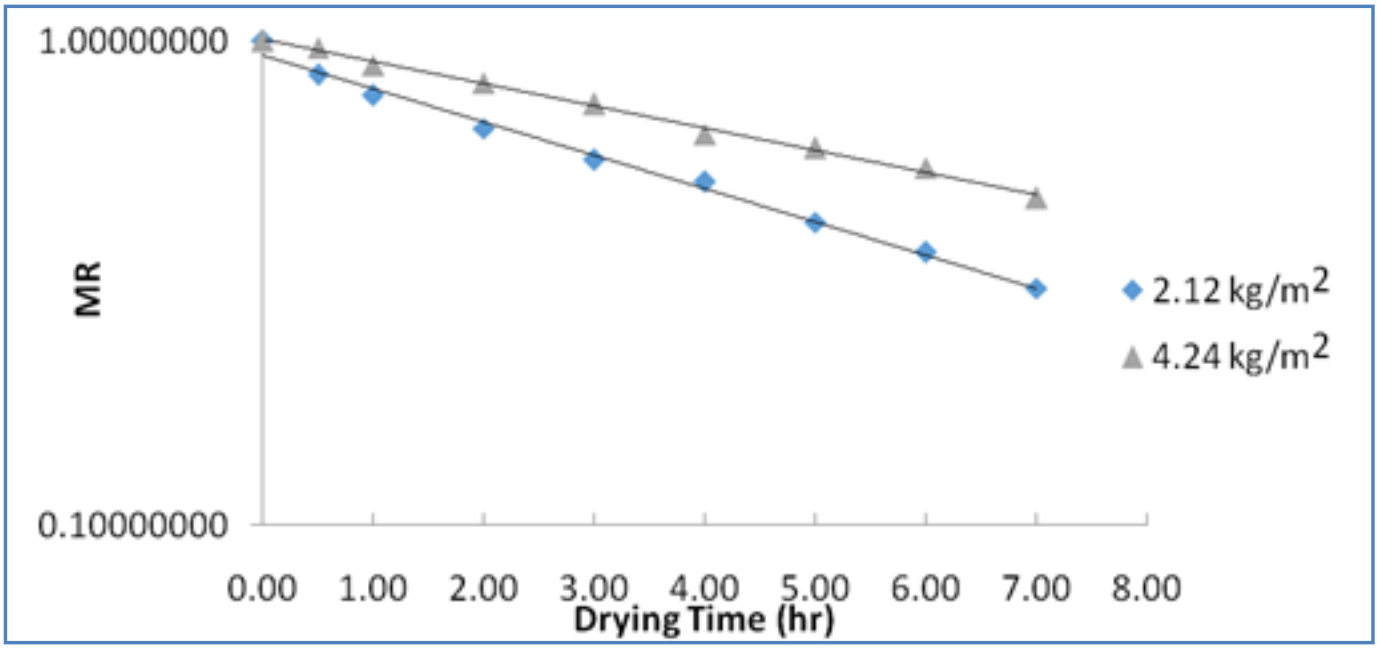

Figure 2 Effect of loading density on drying kinetics of wheat at $40^{\circ} \mathrm{C}$

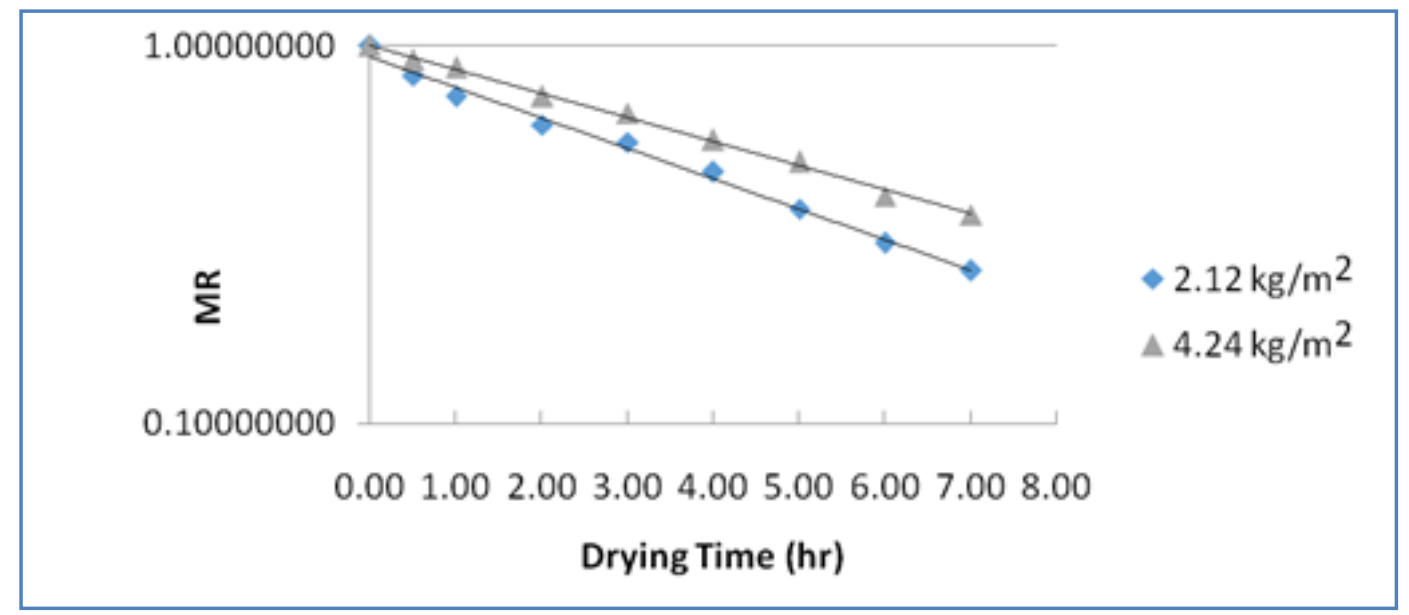

Figure 3 Effect of loading density on drying kinetics of wheat at $45^{\circ} \mathrm{C}$. 


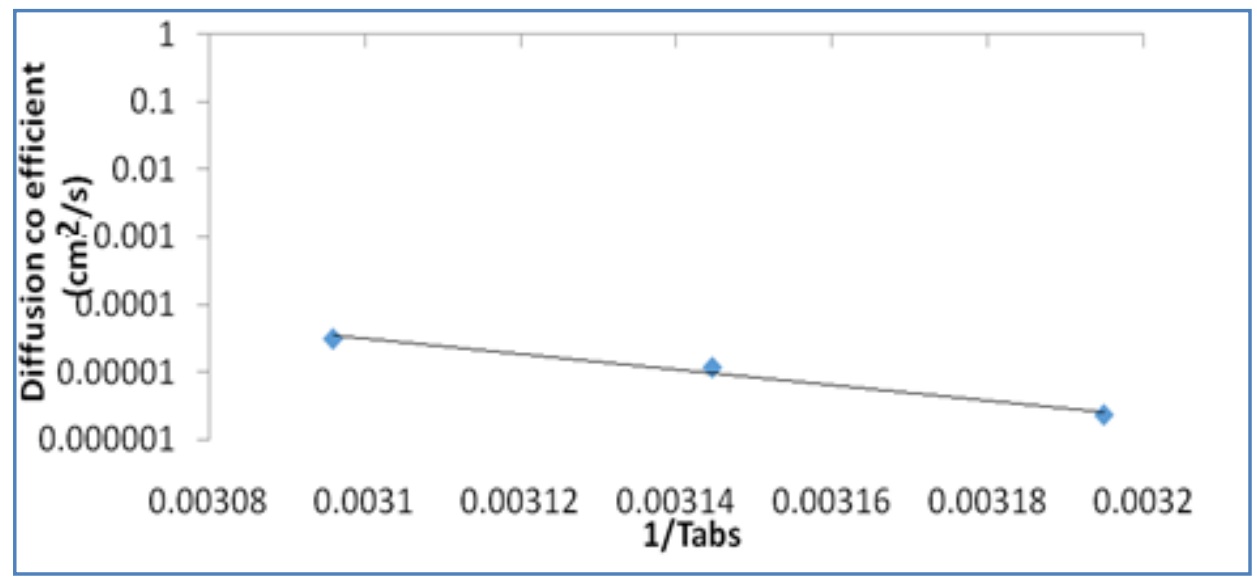

Figure 5 Effect of temperature on diffusion coefficient

\section{Conclusion}

The Henderson and Pabis model was used to fit different drying conditions for wheat in cabinet drying system. The model revealed that drying of wheat could be accomplished commercially by cabinet dryer. It was observed that drying time to a specific moisture ratio decreased with higher drying temperature. On the other hand, loading density of wheat showed negative effect on drying rate constant.The effective moisture diffusivity varied from $3.27 \times 10-11 \mathrm{~cm}^{2} / \mathrm{sec}$ to $7.95 \times 10-11 \mathrm{~cm}^{2} / \mathrm{sec}$ with a temperature range of 40 to $50^{\circ} \mathrm{C}$ and was found to be increased with the increasing of temperature. Furthermore, activation energy $\left(E_{a}\right)$ was found $17.64 \mathrm{kcal} / \mathrm{g}$-mole. Drying temperature of $50^{\circ} \mathrm{C}$ with loading density of $2.12 \mathrm{~kg} / \mathrm{m}^{2}$ could be suggested for drying of wheat incabinet drying process.

\section{Conflict of interest}

Authors would hereby like to declare that there is no conflict of interests that could possibly arise.

\section{References}

Abe T, Afzal TM (1997) Thin-layer infrared radiation drying of rough rice. Journal of Agricultural Engineering Research 67: 289-297. DOI:10.1006/jaer.1997.0170

Afzal Babu SMM, KowserSarker MAS, Islam MN (1997) Kinetics of mechanical solar and sun drying of onion. Bangladesh Journal of Agricultural Engineering 8: 49-61.

Akgun NA, Doymaz I (2005) Modeling of olive cake thinlayer drying process. Journal of Food Engineering 68:455-461. DOI:10.1016/j.jfoodeng.2004.06.023

Alam MM, Hossain MZ, Aktar M, Islam MS, Hasan Z (2014a) Drying and Dehydration Kinetics of Ginger. International Journal of Innovation and Applied Studies 9: 956-967.
Alam MM, Islam MN, Islam MN (2014b) Study on drying kinetics of summer onion. Bangladesh Journal of Agricultural Engineering 39 : 661-673.

Bala BK, Haque MA, Hossain MA, Majumdar S (2010) Post Harvest Loss and TechnicalEfficiency of Rice, Wheat and Maize Production System: Assessment and Measures for Strengthening Food Security. Bangladesh Agricultural University.

Banglapedia (2006) BANGLAPEDIA-national encyclopedia of Bangladesh. Available on http://www.banglapedia.org/httpdocs/HT/W_0053.htm access on 20 February, 2016.

Brooker DB, Bakker FW, Hall CW (1974) Drying. The AVI Pub. C. Ine. U.S.A.: 185 .

Crank J (1975) The mathematics of diffusion. Clarendom Press, Oxford.

Da Silva CKF, Da Silva ZE, Mariani VC (2009) Determination of the diffusion coefficient of drymushrooms using the inverse method. Journal of Food Engineering 95: 1-10. DOI:10.1016/j.jfoodeng.2009.04.009

Erenturk S, Erenturk K (2007) Comparison of genetic algorithm and neural network approaches for the drying process of carrot. Journal of Food Engineering 78: 905-912. DOI:10.1016/j.jfoodeng.2005.11.031

Ertekin C, Yaldiz O (2004) Drying of eggplant and selection of a suitable thin layer drying model. Journal of Food Engineering 63: 349-359. DOI:10.1016/j.jfoodeng.2003.08.007 
Figiel A (2010) Drying kinetics and quality of beetroots dehydrated by combination of convective and vacuummicrowave methods. Journal of Food Engineering 98: 461470. DOI:10.1016/j.jfoodeng.2010.01.029

Ginger SA, Mascheroni RH (2001) Difusive Drying Kinetics in Wheat, Part 2:

applying the Simplified Analytical Solution to Experimental Data. Biosystems Engineering 81: 85-97. DOI:10.1006/bioe.2001.0004

Iqbal A (2003) Processing and preservation of cauliflower and cucumber by dehydrationand fermentation. M.S. thesis submitted to Department of Food Technology and Rural Industries, Bangladesh Agricultural University, Mymensingh, Bangladesh.

Islam MN (1980) Use of solar energy for development of shelf-stable potato product. Ph.D. Thesis submitted to Royal Veterinary and Agriculture University, Copenhagen, Denmark.

Islam MN, Uddin MB, Islam NM (1997) Development of selfstabledehydration mango products. Bangladesh Journal of Agricultural Engineering 4: 65-73.

Izadifar M, Mowla D (2003) Simulation of Cross-Flow Continuous Fluidized Bed Dryer for Paddy Rice. Journal of Food Engineering 58: 325-329. DOI:10.1016/S02608774(02)00395-3

Kamrul N (2006) Effect of Conditions on Milling Quality and Germination of Paddy. M.S. Thesis submitted to Department of Food Technology and Rural Industries, Bangladesh Agricultural University, Mymensingh.

Kamruzzaman M, Islam MN (2006) Kinetics of dehydration of aroids and developed dehydrated aroids products. Journal of Chemical Engineering, IEB 24: 19-24. DOI: http://dx.doi.org/10.3329/jce.v24i0.5579

Karathanos VT, Villalobos G, Saravacos GD (1990) Comparison of two methods of effective moisture diffusivity from drying data. Journal of Food Science 55: 218-231. DOI: 10.1111/j.1365-2621.1990.tb06056.x

Karel M, Fennema OR and Lund DB(1975) Principle of Food Science, Part II, Physical principles of Food Preservation. Marcel Deker, Inc. New York and Basel.

Khaliduzzaman, Al-Emran M, Shams-Ud-Din M (2009) Studies on the preparation of shelf-stable garlic powder. Bangladesh Research Publications Journal 2: 578-584.

Kingsly ARP, Singh DB (2007) Drying kinetics of pomegranate arils. Journal of Food Engineering 79:741-744. DOI:10.1016/j.jfoodeng.2006.02.033
Kumar N, Sarkar BC, Sharma HK (2011) Effect of air velocity on kinetics of thin layer carrot pomace drying. Food Science and Technology International 17: 439-447. DOI: $10.1177 / 1082013211398832$

Madamba PS, Driscoll RH, Buckle KA (1996) The thin layer dryingcharacteristics of garlic slices. Journal of Food Engineering 29:75-97. DOI:10.1016/0260-8774(95)00062-3

Maskan M (2000) Microwave/air and microwave finish drying of banana. Journal of Food Engineering 44: 71-78. DOI:10.1016/S0260-8774(99)00167-3

Midilli A, Kucuk H, Yapar Z (2002) A new model for single layer drying. Drying Technology 20 : 1503-1513.

Ozdemir M, Devres YO (1999) The thin layer drying characteristics of hazelnuts during roasting. Journal of Food Engineering 42:225-233. DOI : 10.1016/S02608774(99)00126-0.

Perry RH, Green DW, Maloney JO (1984) Perry's Chemical Engineers' Handbook. (6th Edn), McGraw-Hill, New York 1320.

Potter NN, Hotchkiss JH (1978) Food Science, CBS Publishers and Distributors, Shahdara, Delhi 78.

Roberts JS, Kidd DR, Zakour OP (2008) Drying kinetics of grape seeds. Journal of Food Engineering 89: 460-465. DOI:10.1016/j.jfoodeng.2008.05.030

Sagar VR, Kumar SP (2010) Recent advances in drying and dehydration of fruits and vegetables: A review. Journal of Food Science and Technology 47: 15-26. DOI: 10.1007/s13197-010-0010-8

Sanjuan N, Lozano M, Garcia-Pascal P, Mulet A (2003) Dehydration kinetics of red pepper (Capsicum annuum $\mathrm{L}$ var Jaranda). Journal of the Science of Food and Agriculture 83:697-701. DOI: 10.1002/jsfa.1334

Sarker A, Islam MN, Shaheb MR (2012) A study on the drying behaviour of a local variety (lalpakri) of potato (Solanum tuberosum L.). Bangladesh Journal of Agricultural Research 37: 505-514.

Sharma GP, Verma RC, Pankaj P (2005) Mathematical modeling of infrared radiation thin layer drying of onion slices. Journal of Food Engineering 71: 282-286. DOI:10.1016/j.jfoodeng.2005.02.010

Sramkova Z, Gregova E, Sturdik E (2009) Chemical composition and nutritional quality of wheat grain. Acta Chimica Slovaca $2: 115-138$. 
Tutuncu MA, Labuza TP (1996) Effect of geometry on the effective moisture transfer diffusion coefficient. Journal of Food Engineering $30: 433-447 . \quad$ DOI:10.1016/S02608774(96)00028-3

Wang Z, Sun J, Liao X, Chen F, Zhao G, Wu J, Hu X (2006) Mathematical modelling on hot air drying of thin layer apple pomace. Food Research International 40:39-46. DOI:10.1016/j.foodres.2006.07.017
Zogzas NP, Maroulis ZB, Marinos-Kouris D (1996) Moisture diffusivity data compilation in foodstuffs. Drying Technology 14: $2225-2253$.

Zohary D, Hopf M (2000) Domestication of plants in the old world. 3rd Edition, Oxford. 